\title{
INFLUENCE OF DIFFERENT FOOD ADDITIVES AND INGREDIENTS ON THE TECHNOLOGICAL CHARACTERISTICS OF ANIMAL PROTEINS
}

\author{
ВЛИЯНИЕ РАЗЛИЧНЫХ ПИЩЕВЫХ ДОБАВОК \\ И ИНГРЕДИЕНТОВ НА ТЕХНОЛОГИЧЕСКИЕ ХАРАКТЕРИСТИКИ \\ ЖИВОТНЫХ БЕЛКОВ
}

\author{
Drozdova N. A., Nasonova V. V. \\ The V.M. Gorbatov All-Russian Meat Research Institute, Moscow, Russia
}

Ключевые слова: коллагенсодержащий белок, температура денатурации коллагена, действие солей/кислот/щелочей на коллаген.

\section{Аннотация}

В данной статье представляется информация о функиионально-технологических свойствах коллагенсодержащих белков. Рассмотрены особенности строения коллагена, зависимость температуры денатурации от содержания пролина и гидроксипролина. Представлены данные об изменениях в структуре коллагена в условиях тепловой обработки. После охлаждения сваренного коллагена в результате образуются прочные студни, способные удерживать большое котичество воды.

Описано влияние уровня рН на температуру денатурации, растворимость коллагена в воде, прочностные характеристики коллагенсодержаших белков.

Приведены данные о степени влияния различных пищевых добавок и химических веществ, а именно кислот и щелочей, солей, фосфатов, гидроколлоидов на структуру и функиионально-технологические свойства коллагенсодержащего белка. Влияние кислот, щелочей, солей на свойства коллагена зависит от природы и силь ионов и их сродства с ионами коллагенового белка. Взаимодействие коллагеновых белков и гидроколлоидов приводит к синергетическому эфбекту. Фосфать вместе с коллагеном образуют прочные структурь.

\section{Введение}

Благодаря своим уникальным свойствам, коллагенсодержащие препараты находят широкое применение в медицине, ветеринарии, отраслях пищевой и легкой промышленности. Однако, коллаген сложно выделить из соединительной ткани и перевести в растворенное состояние [1]. Существуют различные способы получения коллагенсодержащего белка, от которых зависят его характеристики и свойства. Специфичность коллагена обусловлена его высокой молекулярной массой, значительным количеством активных полярных групп, низкой термостабильностью и др [1].

Применение коллагеновых белков в мясоперерабатывающей промышленности позволяет улучшить консистенцию и структурно-механические свойства мясной продукции, исключить бульоно-жировые оттеки при изготовлении колбасных изделий, достичь желаемой монолитности, нарезаемости и «кусаемости» мясного продукта. Одно из преимуществ использования коллагеновых
Keywords: collagen protein, $\mathrm{pH}$, denaturation temperature, influence salts/acids/alkalis on collagen.

\section{Abstract}

In the present review, we focus on the features of the collagen structure. In particular, we report the correlation between the amount of proline and hydroxyproline and the temperature of denaturation, as well as the changes of collagen structure after thermal treatment. After cooling, denaturated collagen forms dense jellies which may absorb a large amount of water. The influence of $\mathrm{pH}$ on the denaturalion temperature, solubility and the strength characteristics of collagen-containing proteins are described. The review also describes the data on the influence of various food additives and chemicals (acids, alkalis, salts i.a. phosphates, hydrocolloids) on the collagen protein structure and technological properties.

The effect of acids, alkalis, salts on the properties of collagen depends on the nature and strength of the ions and their affinity for the collagen ions. The interactions between the collagen proteins and hydrocolloids result in the synergetic effect. Phosphates and collagen form solid structures.

\section{Introduction}

Due to its unique properties, collagen-containing preparations find wide use in medicine, veterinary, sectors of food and light industries. However, it is difficult to extract collagen from the connective tissue and transform it into the solubilized condition [1]. Collagen protein can be obtained by different methods, on which its characteristics depend. The specificity of collagen is conditioned by its high molecular weight, significant amount of the active polar groups, low thermal stability and so on [1].

The use of collagen proteins in the meat processing industry allows improving consistency and structural and mechanical properties of meat products, prevent brothfatty purge in production of sausage products and achieve the desired monolithic structure, cutting and biting properties of meat products. One of the advantages of using collagen proteins is a decrease in cooking and storage losses, which results in high yields and stable quality of finished 
белков это снижение потерь при термической обработке и хранении и, как результат, высокий выход и стабильное качество готовой продукции, улучшение экономических показателей производства мясных изделий.

Высокая функциональность коллагеновых белков позволяет использовать их в производстве эмульгированных, реструктурированных, цельномышечных изделий и полуфабрикатов. На основе коллагеновых белков готовят гели, эмульсии, гранулы или используют их без предварительной подготовки в сухом виде, внося непосредственно в фарш или в рассол [2].

В формировании функционально-технологических свойств коллагеновых белков важную роль играет строение коллагена. Известно более 27 видов коллагенов, но наиболее распространенным в мясоперерабатывающей промышленности является фибриллярный коллаген типа I. Промежуточные молекулы коллагена состоят из трех-цепочечной спиральной структуры, в основе которой находится многочисленно повторяющийся трипептид Gly-X-Y, где в большинстве случаев $\mathrm{X}$ является пролином, а Y гидроксипролином $[3,4,5]$. Эта последовательность является основным фактором термостабильности $[6,7]$.

Содержание пролина и гидроксипролина особенно важно для желирующего эффекта. Между тем, гидроксипролин, как полагают Hashim, Mohd Ridzwan и др [6], играет особую роль в стабилизации тройной спирали коллагена благодаря способности образовывать водородные связи через -ОН группы $[3,6]$. Суммарное содержание данных пирролидиновых остатков оказывает влияние и на температуру денатурации: чем больше их количественное содержание в белке, тем выше температура денатурации [5]. Денатурация коллагена происходит при различных температурах в пределах $58 . .67^{\circ} \mathrm{C}$. Кроме содержания пролина и гидроксипролина температура денатурации зависит от того, из какого сырья получен белок.

При нагревании до температуры денатурации часть водородных связей коллагена, удерживающих полипептидные цепи в третичной структуре, ослабевает и разрывается. Коллагеновый белок в растворе сваривается, его структурные связи полностью разрушаются. В результате изменения нативной структуры коллагена (пептизации) происходит увеличение количества активных групп (-COOH и -OH), играющих роль гидрофильных центров [8]. Процесс деструкции коллагена необратимый и считается началом денатурации фибриллярного белка $[8,9]$. После тепловой обработки при температуре денатурации происходит трансформация коллагена с образованием соединений меньшей молекулярной массой: желатина, желатозы, глютина, которые после охлаждения образуют прочные студни $[2,8,10]$. Переход коллагена в глютин ускоряет не только температура, но и кислая среда.

Функционально-технологические свойства коллагенсодержащих белков, а также мясных (фаршевых) products and improved economic indicators in meat product manufacture.

High functionality of collagen proteins allows their use in production of emulsified, restructured and whole muscle products, as well as semi-prepared products. Based on the collagen proteins, gels, emulsions and granules are prepared and used in a dried form without preliminary preparation by adding directly into minced meat or brine [2].

The collagen structure plays an important role in formation of the functional and technological properties of collagen. More than 27 types of collagens are known; however, fibrillar collagen type $\mathrm{I}$ is the most common in the meat industry.

The transient molecules of collagen consist of the triplehelical structure, the basis of which is multiply repeated tripeptide Gly-X-Y, where in most cases $\mathrm{X}$ is proline and $\mathrm{Y}$ is hydroxyproline $[3,4,5]$. This sequence is the main factor of thermal stability $[6,7]$.

The proline and hydroxyproline content is especially important for the gelling effect. At the same time, hydroxyproline, as Hashim, Mohd Ridzwan et al. [6] suggest, plays a specific role in stabilization of the collagen triple helix due to the ability to form the hydrogen bonds though -OH groups $[3,6]$.

The total content of pyrrolidine residues also affects the denaturation temperature: the more their quantitative content in protein, the higher the denaturation temperature [5]. Denaturation of collagen occurs at different temperatures in a range of $58 . .67^{\circ} \mathrm{C}$. In addition to the proline and hydroxyproline content, the denaturation temperature depends on raw material, from which protein was obtained.

When heating up to the denaturation temperature, part of the collagen hydrogen bonds, which hold polypeptide chains in the tertiary structure, weakens and ruptures. Collagen protein in a solution shrinks; its structure is fully destroyed. As a result of the changes in the collagen native structure (peptization), an amount of the active groups $(-\mathrm{COOH}$ and $-\mathrm{OH})$, which play a role of the hydrophilic centers, increases [8]. The process of collagen destruction is irreversible and is considered the beginning of fibrillar protein denaturation $[8,9]$. After thermal treatment at the denaturation temperature, the transformation of collagen occurs with formation of compounds with the lower molecular weights: gelatin, gelatose and glutin, which form strong gels after cooling $[2,8,10]$. Transition of collagen into glutin is accelerated not only by a temperature, but also by an acid medium.

The functional and technological properties of collagen proteins, as well as meat (forcemeat) systems obtained with their use, significantly depend on the $\mathrm{pH}$ value of their aqueous solutions. It is known that the isoelectric point 
систем, получаемых с их использованием, существенным образом зависят от значения $\mathrm{pH}$ их водных растворов. Известно, что изоэлектрическая точка мышечных белков приходится на значения рН от 5,0 и ниже (кислая среда), тогда как изоэлектрическая точка коллагенсодержащих белков лежит в области рН от 6,0 до 6,75. При уменьшении рН снижается изометрическое напряжение коллагеновых волокон [9]. Сдвиг рН в щелочную или кислую сторону приводит к изменению распределения положительных и отрицательных зарядов на поверхности молекулы белка и, следовательно, к изменению их функциональных свойств [11]. Так, при рН = 3 температура денатурации коллагена $\left(\mathrm{T}_{\mathrm{d}}\right)$ снижается до $35-40^{\circ} \mathrm{C}$, при $\mathrm{pH}=1 \mathrm{~T}_{\mathrm{d}}$ составляет $30^{\circ} \mathrm{C}[12,13]$.

Уровень $\mathrm{pH}$ оказывает влияние и на растворимость коллагена в воде. Увеличение ионной силы влияет на снижение растворимости коллагена. В работе [14] процент растворимого коллагена был ниже при $\mathrm{pH}=7,4$, чем при 5,6.

Проведены исследования [15] на модельных образцах сырокопченых колбас с использованием животного белка с различным уровнем $\mathrm{pH}$. В промышленных условиях гели, образованные животным белком с $\mathrm{pH}=3,5$, получались более прочными и равномерными по сравнению с гелями белка, $\mathrm{pH}$ которого составлял 6,4 [15].

При низких значениях рН происходит разрушение ковалентных связей и некоторых специфичных пептидных связей [9]. Обобщая влияние уровня $\mathrm{pH}$, можно сказать, что низкое значение $\mathrm{pH}$ увеличивает процент растворимого коллагена, ускоряет процесс разваривания коллагена и образования глютина и желатина, тем самым оказывая влияние на образование прочных гелей.

Безусловно, не только уровень рН влияет на прочностные характеристики гелей животного белка, но и добавляемые к белку другие ингредиенты. По этой причине представлялся интерес изучить влияние различных пищевых добавок и условий на функционально- технологические характеристики коллагенсодержащих белков.

\section{Влияние кислот и щелочей на коллаген}

Коллаген обладает способностью реагировать как с кислотами, так и с щелочами. Карбоксильные и осноњные группы аминокислотных остатков, примыкающие к $а$-углеродным атомам конечных аминокислот, заметного влияния на взаимодействие коллагена с кислотами и щелочами не оказывают. Также на протеолитическое равновесие в структуре коллагена незначительно влияние амидов некоторых остатков аспарагиновой и глютаминовой кислот, гидроксилов и пептидных [12].

В случае, если рН нейтрального значения, происходит взаимная компенсация противоположных зарядов боковых цепей остатков аминокислот (таких как аргинин, аспарагиновая и глутаминовая кислоты и др. (рис. 1a). [16, 17]. of muscle proteins is at a $\mathrm{pH}$ value of 5.0 or lower (acid medium); while, the isoelectric point of collagen proteins is in a $\mathrm{pH}$ range of 6.0 to 6.75 . With a decrease in $\mathrm{pH}$, the isometric tension of collagen fibers reduces [9]. The $\mathrm{pH}$ shift to an alkaline or acidic region leads to the changes in distribution of the positive and negative charges on a protein molecular surface and, consequently, to the changes in their functional properties [11]. For example, at $\mathrm{pH}=3$, a temperature of collagen denaturation $\left(\mathrm{T}_{\mathrm{d}}\right)$ reduces to $35-40^{\circ} \mathrm{C}$; at $\mathrm{pH}=1, \mathrm{~T}_{\mathrm{d}}$ is $30^{\circ} \mathrm{C}[12,13]$.

The $\mathrm{pH}$ value also influences collagen solubility in water. An increase in the ionic strength affects a decrease in the collagen solubility. In the work [14], the percentage of soluble collagen was lower at $\mathrm{pH} 7.4$ than at $\mathrm{pH}=5.6$.

The study [15] on the model samples of uncooked smoked sausages with the use of animal protein with different values of $\mathrm{pH}$ was carried out. In the industrial conditions, the gels produced by animal proteins with $\mathrm{pH}=3.5$ were stronger and more homogeneous compared to the protein gels with $\mathrm{pH}=6.4$ [15].

At low pH values, the covalent bonds and several specific peptide bonds are broken down [9]. Generalizing an effect of a $\mathrm{pH}$ value, it can be said that low $\mathrm{pH}$ values increase a percentage of dissolved collagen, accelerate the process of collagen digestion and formation of glutin and gelatin, thereby, influencing formation of strong gels.

Undoubtedly, not only $\mathrm{pH}$ values affect the strength characteristics of animal protein gels, but also other ingredients added to protein. Therefore, it seems interesting to study an impact of different food additives and conditions on the functional and technological characteristics of collagen proteins.

\section{Effect of acids and alkalis on collagen}

Collagen has an ability to react both with acids and alkalis. Carboxyl and basic groups of amino acid residues, adjacent to $a$-carbon atoms of the terminal amino acids do not affect significantly an interaction of collagen with acids and alkalis. Several residues of aspartic and glutamic acids, hydroxyls and peptide residues also influence the proteolytic equilibrium in the collagen structure [12].

In case of neutral $\mathrm{pH}$, the mutual compensation of the opposite charges of the side chains of amino acids (such as agrinine, aspartic and glutamic acids and so on) takes place (Fig. 1a) [16, 17].

However, in the presence of a strong acid, the groups of the basic character become ionized, and those of an acid character are suppressed (Fig. 1b). Molecular chains are deformed due to the electrostatic repulsion, collagen fibers become thicker and, as a consequence, their length reduces $[12,16]$. Gradual destruction of the intermolecular hydrogen bonds and water-bridged structure begins. In this connection, the temperature of collagen denaturation decreases. 
Однако, в присутствии сильной кислоты группы основного характера становятся ионизированными, а кислотного - подавленными (рис. 16). Молекулярные цепи деформируются за счет электростатического отталкивания, происходит утолщение коллагенового волокна и, как следствие, уменьшение его длины $[12,16]$. Начинается постепенное разрушение внутримолекулярных водородных связей и водно-мостиковой структуры. В связи с этим снижается температура денатурации коллагена.

Деформацию цепей белка можно объяснить подавлением заряда карбоксильных групп боковых цепей или заряда групп основного характера белка при добавлении кислоты или щелочи соответственно $[12,17]$. При взаимодействии с кислотами и щелочами степень набухания коллагена увеличивается, однако, степень влияния зависит от силы электролита [17]. Так, например, по интенсивности влияния на степень набухания одноосновные щелочи будут расположены в следующем порядке убывания степени влияния: $\mathrm{KOH}, \mathrm{NaOH}$, $\mathrm{NH}_{4} \mathrm{OH}$ [12]. Увеличение концентрации кислоты и щёлочи вызывает набухание коллагена и в дальнейшем его растворение [17].

Набухание в кислотах происходит в результате суммарного действия осмотических и электростатических сил [17]. Длительная обработка кислотой, например, соляной, вызывает набухание и последующее растворение коллагена [17].

В концентрированных растворах кислот преобладает молекулярная адсорбция с коллагеном в основном по пептидным связям: взаимодействие происходит в направлении водородного связывания карбонильных групп одной цепи с иминогруппами другой [17]. Однако процесс набухания протекает с различной интенсивностью, которая зависит от степени родства аниона кислоты к коллагену. Так, например, большее сродство аниона серной кислоты по сравнению с соляной приводит к большему разрыхлению структуры коллагена, к увеличению степени набухания, а температура сваривания коллагена в серной кислоте ниже, чем в соляной не зависимо от концентрации [17].

Тем не менее, в разбавленном растворе соляной кислоты набухание будет наблюдаться интенсивнее, чем в серной. Это объясняется тем, что для разбавленных кислот основную роль играют процессы ионной сорбции [17].

Изменения в структуре коллагена, вызванные обработкой разбавленными растворами соляной и уксусной кислот, будут однотипными. В разбавленных растворах уксусной кислоты $\left(\mathrm{CH}_{3} \mathrm{COOH}\right)$ взаимодействие происходит у боковых цепей коллагена [17]. Степень диссоциации карбоксильной группы увеличивается при введении электроноакцепторных групп в $\alpha$-положение, таким образом усиливается действие разбавленных растворов кислот. Так, а-оксипропионовая (молочная) кислота $\left[\mathrm{CH}_{3} \mathrm{CH}(\mathrm{OH}) \mathrm{COOH}\right]$ снижает $\mathrm{T}_{\mathrm{d}}$ до $15^{\circ} \mathrm{C}$,

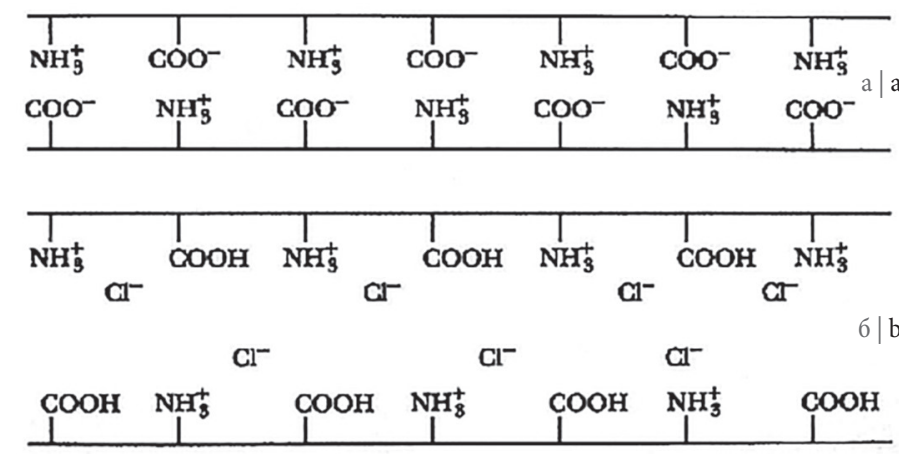

Figure 1. Compensation of the opposite charges in a collagen macromolecule (a) and interaction of protein with an excess of hydrochloric acid (b) [16]

Рис. 1. Компенсация противоположных зарядов в макромолекуле коллагена (а) и взаимодействия белка с избытком соляной кислоты (б) [16]

Deformation of protein chains can be explained by suppression of a charge of the carboxylic groups of the side chains or a charge of the protein groups of the basic character when adding an acid or alkali, respectively [12, 17]. In interaction with acids and alkalis, the degree of collagen swelling increases; however, the degree of the effect depends on the strength of electrolyte [17]. For instance, in terms of the effect intensity, the monobasic alkalis will be arranged in the following order of a decrease in the effect degree: $\mathrm{KOH}, \mathrm{NaOH}, \mathrm{NH}_{4} \mathrm{OH}$ [12]. An increase in the acid or alkali concentration causes swelling of collagen and its following dissolution [17].

Swelling in acids occurs as a result of the summary action of osmotic and electrostatic forces [17]. Durable treatment with an acid, for example, hydrochloric acid, causes swelling and following dissolution of collagen [17].

In the concentrated acid solutions, molecular absorption with collagen (mainly, by peptide bonds) prevails: interaction occurs in the direction of hydrogen bonding of the carbonyl groups of one chain with amino groups of another [17]. However, a process of swelling occurs with different intensity, which depends on the degree of the affinity of the acid anions for collagen. For instance, the high affinity of the anion of sulfuric acid compared to hydrochloric acid leads to significant loosening of the collagen structure and an increase in the degree of swelling; while the thermal shrinkage temperature of collagen in sulfuric acid is lower than in hydrochloric acid independent of concentration [17].

Nevertheless, in the dissolved solution of hydrochloric acid, swelling will be more intensive than in sulfuric acid. This can be explained by the fact that the main role in dissolved acids plays the processes of ionic sorption [17].

Changes in the collagen structure caused by treatment with the dissolved solutions of hydrochloric and acetic acids will be similar. In the dissolved solutions of acetic acid 
и при $20^{\circ} \mathrm{C}$ коллагеновое волокно уже растворяется. Аналогично действие $\alpha$-оксиуксусной (гликолевой) $\left[\mathrm{OHCH}_{2} \mathrm{COOH}\right]$ и трихлоруксусной $\left[\mathrm{CCl}_{3} \mathrm{COOH}\right]$ кислот. Меняя заместителей в а-положении, можно добиться оптимального воздействия органических кислот на коллаген (денатурация, диспергирование, частичное растворение) [16].

Органические слабодиссоциированные кислоты (например, уксусная кислота) сорбируясь как в виде ионов, так и в неионизированной форме, не могут полностью подавить ионизацию основных групп белка. Для разрушения коллагеновой структуры требуются значительная концентрация уксусной кислоты и длительное время воздействия, но полного растворения коллагенового волокна в итоге всё равно не произойдет [16].

В кислой среде белки будут заряжены положительно, находясь в ионизированном состоянии и образовывая с анионами добавленной кислоты соединения типа соли. При добавлении сильного основания заряд белков станет отрицательным, а карбоксильные группы белка в ионизированном состоянии будут представлять собой соединение типа соли с катионом добавленной щёлочи [12].

Однако, изучение взаимодействия различных кислот и щелочей с коллагенсодержащим белком носит индивидуальный характер, т.к. в структуре белка находятся разнообразные функциональные группы. Необходимо учитывать сродство ионов $\mathrm{Na}^{+}$и $\mathrm{Cl}^{-}$с ионогенными группами коллагена в отличие от большинства других ионов, которые взаимодействуют с заряженными центрами структуры коллагены и тем самым нарушают ионное равновесие. По этим причинам представлялся интерес доказать отсутствие влияния $\mathrm{NaCl}$ на функционально-технологические свойства коллагенсодержащих белков.

\section{Воздействие неорганических солей}

Коллагеновый белок в растворах солей подвергается модификациям, которые зависят главным образом от концентрации и вида аниона и катиона. Эти изменения оказывают влияние в первую очередь на набухание коллагена [12].

Установлено, что из разбавленного раствора хлорида натрия коллаген поглощает преимущественно ионы хлора $[12,18]$. Хлорид натрия уменьшает прочность геля коллагеновых белков в связи с тем, что способен отключать гидрофобные и водородные связи. Препятствие стабилизации коллагеновых гелей происходит непосредственно за счет предотвращения образования водородных связей и/или из-за изменения структуры воды в непосредственной близости от этих участков $[19,20]$.

Степень влияния солей можно разделить на три группы по Михайлову А. Н.[12]:

- к первой группе относятся роданаты, иодиды, хлораты, соли бария, кальция, магния и лития - coeдинения, вызывающие сильное набухание коллагена при любых концентрациях;
$\left(\mathrm{CH}_{3} \mathrm{COOH}\right)$, interactions will take place at the side chains of collagen [17]. The degree of dissociation of the carboxyl group increases when adding electron-accepting groups in a-position; thus, the action of the dissolved acid solutions increases.

For example, $\alpha$-oxypropionic (lactic) acid $\left[\mathrm{CH}_{3} \mathrm{CH}(\mathrm{OH})\right.$ $\mathrm{COOH}$ ] decreases $\mathrm{T}_{\mathrm{d}}$ to $15^{\circ} \mathrm{C}$ and a collagen fiber is already dissolved at a temperature of $20^{\circ} \mathrm{C}$. The actions of a-oxyacetic (glycolic) $\left[\mathrm{OHCH}_{2} \mathrm{COOH}\right]$ and trichloroacetic $\left[\mathrm{CCl}_{3} \mathrm{COOH}\right]$ acids are similar. By changing substituents in the $\alpha$-positions, it is possible to achieve an optimal effect of the organic acids on collagen (denaturation, dispersion, partial dissolution) [16].

The organic weakly dissociated acids (for example, acetic acid) sorbing both in a form of ions and in the nonionized form cannot fully suppress ionization of protein basic groups. To destroy the collagen structure, a significant concentration of acetic acid and durable time of its exposure are required, but, eventually, the full dissolution of collagen fibers will not occur [16].

In the acid medium, proteins will be charged positively being in the ionized condition and forming compounds like salts with anions of the added acid. On addition of a strong base, a protein charge will become negative and carboxyl groups of proteins in the ionized condition will present compounds like salts with a cation of an added alkali [12].

However, a study of the interaction of different acids and alkalis with collagen protein has an individual character as various functional groups are in the structure of proteins. It is necessary to take into consideration the affinity of $\mathrm{Na}^{+}$and $\mathrm{Cl}^{-}$ions for the ionogenic groups of collagen in contrast to the majority of other ions, which interact with the charged centers of the collagen structure and, thus, disturb the ionic balance. For these reasons, it was interesting to prove an absence of the $\mathrm{NaCl}$ effect on the functional and technological properties of collagen proteins.

\section{Effect of inorganic salts}

Collagen protein in the salt solutions was subjected to modifications, which mainly depend on a concentration and a type of anion and cation. These changes primarily influence swelling of collagen [12].

It was established that collagen absorbs mainly the chlorine ions from the dissolved sodium chloride solution $[12,18]$. Sodium chloride reduces the strength of collagen protein gels due to its ability to switch off the hydrophobic and hydrogen bonds. A hurdle for stabilization of collagen gels occurs directly due to prevention of formation of the hydrogen bonds and/or changes in water structure in the direct closeness of these regions $[19,20]$.

The degree of the influence of salts can be divided into three groups according to Mikhailov A.N. [12]: 
- ко второй группе - хлорид натрия и другие соли, которые не оказывают значительного влияния на свойства коллагена;

- в третью группу входят соли, ион которых не отличается повышенной адсорбируемостью и обладает высаливающими свойствами, например, сульфаты, тиосульфаты, ацетаты и карбонаты.

В случае солей первой группы коллагеновые волокна при набухании укорачиваются и утолщаются, а температура сваривания резко снижается, коллаген способен свариваться уже при комнатной температуре. При взаимодействии коллагена с солями второй группы происходит небольшое набухание при низких концентрациях соли, в случае использования высоких концентраций - небольшое обезвоживание.

\section{Взаимодействие с гидроколлоидами}

Коллагенсодержащие белки положительно взаимодействуют с различными гидроколлоидами, например, в ряде работ $[2,4,21,22,23]$ описан синергетический эффект животного белка с ними.

Так, при добавлении 1\% каррагинана в 2,5\%-ный гель животного белка марки ScanPro T95 прочность и пластичность геля увеличивалась в 6,3 раза и в 5,9 раза по сравнению с 2,5\%-ным гелем животного белка. Также показан синергетический эффект животного белка и каррагинана в присутствии 2\% поваренной соли [23].

Каррагинаны и другие полисахариды, такие как, например, геллановая камедь, гидроксипропилметилцеллюлоза увеличивают прочность гелей и их термостабильность, что было показано на примере рыбного коллагенсодержащего белка [4].

В работе [22] рассмотрено положительное влияние альгинатов на функциональность белковой системы. На примере белка марки ScanPro CE 40 показано взаимодействие с альгинатами и получение более сильного геля уже после двух часов выдержки. Из-за более эффективного процесса гелеобразования стало возможным сократить время производства и сэкономить затраты на электроэнергию. Другим преимуществом взаимодействия животного белка и альгинатов является термостабильность гелей или эмульсий $[2,22]$.

Авторами Changdao, Fang и др [21] описано получение гидрогеля из коллагенового белка и диальдегидного крахмала. Образование прочного геля достигается за счет реакции альдегидных групп крахмала со свободными аминогруппами в коллагене. При этом третичная структура коллагена не меняется. В результате получается термостабильный гель.

\section{Влияние фосфатов}

В работе [24] готовили четыре эмульсии с различным содержанием коллагена и щелочным фосфатом. Добавление 0,25\% триполифосфата натрия улучшало стабильность эмульсии. Применение коллагена с полифосфатами в сравнении с коллагеном без фосфатов или
- The compounds that cause strong swelling of collagen in any concentrations (rhodanates, iodides, chlorates, barium salts) are in the first group;

- Sodium chloride and other salts, which do not significantly affect the collagen properties, are in the second group;

- The salts, which ions do not have increased absorbability and has salting-out properties, for example, sulfates, thiosulfates, acetates and carbonates are in the third group.

In case of the salts from the first group, collagen fibers shorten and thicken when swelling, and the shrinkage temperature sharply reduces; collagen is able to shrink already at room temperature. Upon interaction of collagen with the salts of the second group, small swelling at low concentrations of salts and small dehydration in case of high concentrations occur.

\section{Interaction with hydrocolloids}

Collagen proteins positively interact with different hydrocolloids. In several works [2, 4, 21, 22, 23], a synergetic effect of animal proteins with them is described. For example, when adding $1 \%$ of carrageenan into $2.5 \%$ animal protein gel of ScanPro T95 brand, the strength and plasticity of gel increased by 6.3 times and 5.9 times compared to $2.5 \%$ animal protein gel. Also, a synergetic effect of an animal protein and carrageenan in the presence of $2 \%$ of table salt was showed [23].

Carrageenans and other polysaccharides, such as gellan gum and hydroxy propyl methyl cellulose, increase the strength and thermal stability of gels, which was shown by the example of fish collagen proteins [4].

In the work [22], a positive effect of alginates on functionality of a protein system was examined. By the example of protein of ScanPro CE 40, an interaction with alginates and production of a stronger gel already after two hours of holding was demonstrated. Due to more effective process of gel formation, it became possible to reduce the time of production and electricity costs. Another benefit of interaction of an animal protein and alginates is thermal stability of gels and emulsions [2, 22].

Changdao, Fang et al. [21] describe production of a hydrogel from collagen protein and dialdehyde starch. Formation of a strong gel is achieved due to the reaction of the aldehyde groups of starch with free amino groups in collagen. With that, the tertiary structure of collagen does not change. As a result, a thermally stable gel is obtained.

\section{Effect of phosphates}

In the work [24], four emulsions with different content of collagen and alkaline phosphate were prepared. Addition of $0.25 \%$ sodium tripolyphosphate improved the emulsion stability. The use of collagen with polyphosphates 
с ортофосфатами увеличивало количество связанной воды, улучшало консистенцию готовой продукции [1].

В работе [25] проводили исследования получения прочных композитов, образованных коллагеном и двухосновным фосфат натрия $\left(\mathrm{Na}_{2} \mathrm{HPO}_{4}\right)$ c $\mathrm{pH}$ около 14. Предварительно коллаген типа I выдерживали в растворе, содержащем анионы $\mathrm{PO}_{4}^{3-}$, затем погружали в раствор, насыщенный катионами $\mathrm{Ca}^{2+}$, чтобы таким образом образовалось осаждение минерала.

\section{Выводы}

В результате проведенного анализа литературы установлены особенности функционально-технологических свойств коллагеновых белков в зависимости от сложности их структуры. Последовательность трипептида, состоящего из глицина, пролина и гидроксипролина, влияет на термостабильность коллагена и желирующий эффект.

Температура денатурации зависит от содержания пролина и гидроксипролина, а также от исходного сырья. При большом содержании пирролидиновых остатков температура денатурации будет выше.

После денатурации коллагена образуются соединения меньшей молекулярной массой: желатина, желатозы, глютина, которые после охлаждения образуют прочные студни, способные удерживать большое количество воды в своей структуре. На трансформацию коллагена в глютин влияют температура и уровень $\mathrm{pH}$.

Выявлена зависимость степени растворимости, температуры сваривания коллагеновых животных белков и прочностных характеристик их гелей от уровня $\mathrm{pH}$. Процент растворимого коллагена выше при значениях $\mathrm{pH}=5,4$, чем при 7,4. В кислой среде денатурация коллагена происходит при низких температурах так, например, при $\mathrm{pH}=3$ температура сваривания составляет $35 \ldots 40^{\circ} \mathrm{C}$, при $\mathrm{pH}=1 \mathrm{~T}_{\mathrm{d}}$ равна $30^{\circ} \mathrm{C}$.

Влияние кислот, щелочей и солей на функциональные свойства коллагеновых белков носит индивидуальный характер, зависит от природы и силы анионов и катионов, их сродства с коллагеновым белком. Например, хлораты, йодиды, соли кальция и магния вызывают сильное набухание коллагена, в то время как хлорид натрия не вызывает значительных изменений в строении коллагена.

Имеет место синергетический эффект животного белка с гидроколлоидами. Использование животного белка в комбинации с каррагинанами или другими полисахаридами (геллановая камедь, гидроксипропилметилцеллюлоза, крахмалы) увеличивает прочность гелей и их термостабильность.

Фосфаты вместе с коллагеном способны образовывать прочные композиты.

Представляет интерес дальнейшее изучение влияния других видов солей, фосфатов и гидроколлоидов на прочностные характеристики гелей коллагеновых белков. increased an amount of bound water and improved consistence of finished products compared to collagen without phosphates or ortophosphates [1].

The work [25] studied production of the strong composites formed by collagen and sodium phosphate dibasic $\left(\mathrm{Na}_{2} \mathrm{HPO}_{4}\right)$ with $\mathrm{pH}$ about 14 . Preliminary collagen of type I was held in a solution contained anions $\mathrm{PO}_{4}^{3-}$; then, it was dipped into a solution saturated with cations $\mathrm{Ca}^{2+}$ to precipitate the mineral.

\section{Conclusions}

As a result of the performed analysis of the literature, the peculiarities of the functional and technological properties of collagen proteins dependent on the complexity of their structure were established. The sequence of tripeptide that is composed from glycine, proline and hydroxyproline affects the thermal stability of collagen and the gelling effect.

The denaturation temperature depends on the content of proline and hydroxyproline as well as on the initial raw material. Upon the high content of the pyrrolidin residues, the denaturation temperature will be higher.

After collagen denaturation, the compounds with lower molecular weight are formed: gelatin, gelatinose and glutin, which, after cooling, form strong gels capable of retaining high amounts of water in their structure. The collagen transformation into glutin is influenced by a temperature and $\mathrm{pH}$ value.

The dependency of the degree of dissolubility, shrinkage temperature of collagen animal proteins and strength characteristics of their gels on a $\mathrm{pH}$ value was established. Percentage of dissolved collagen is higher at $\mathrm{pH} 5.4 \mathrm{com}$ pared to $\mathrm{pH}$ 7.4. In the acidic medium, collagen denaturation occurs at how temperatures; for example, the shrinkage temperature at $\mathrm{pH} 3$ is $35 \ldots 40^{\circ} \mathrm{C}$; at $\mathrm{pH} 1, \mathrm{~T}_{\mathrm{d}}$ is $30^{\circ} \mathrm{C}$.

An effect of acids, alkilis and salts on the functional properties of collagen proteins has an individual character, depends on the nature and strength of anions and cations and their affinity for collagen protein. For instance, chlorates, iodides, calcium and magnesium salts cause strong swelling of collagen; while, sodium chloride does not cause significant changes in the collagen structure.

The synergetic effect of animal proteins with hydrocolloids exists. The use of animal proteins with combination of carrageenans or other polysaccharides (gellan gum, hydroxy propyl methyl cellulose and starches) increases the strength and thermal stability of gels.

Phosphates with collagen are able to form strong composites.

It should be interesting to further study an effect of other types of salts, phosphates and hydrocolloids on the strength characteristics of collagen protein gels. 
БИБЛИОГРАФИЧЕСКИИ СПЛСОК

1. Глотова И.А. Реологические характеристики полифункциональных дисперсионных систем на основе комагеновых белков животных тканей / И.А. Глотова, Ю.В. Болтыхов // Успехи современного естествознания. - 2008. - №2. - С. 43-44.

2. Омаров Р.С. Белки животного происхождения в производстве мясопродуктов / Р.С. Омаров, О.В. Сычева, С.Н. ШАыков // Мясная индустрия. - 2011. - №3. - С. 36-38.

3. Некиюдов А.А., Иванкин А.Н. Комаген: получение, свойства и применение. - М.: ГОУ ВПО МГУА. - 2007. С. 12.

4. Gomez-Guillen M.C. Functional and bioactive properties of collagen and gelatin from alternative sources / M.C. GomezGuillen, B. Gimenez, M.E. Lopez-Caballero, M.P. Montero // Food Hydrocolloids. -2011. -№25. -P. 1813-1827.

5. Rizk M. A, Mostafa N. Y. Extraction and Characterization of Collagen from Buffalo Skin for Biomedical Applications. Orient J Chem 2016;32(3)

6. Hashim et al. Collagen in food and beverage industries / P. Hashim, M. S. Mohd Ridzwan, J. Bakar, D. Mat Hashim // International Food Research Journal. - 2015. - V.22(1). P. 1-8.

7. Zhang Y. General Solution for Stabilizing Triple Helical Collagen. / Y. Zhang, M. Herling, D.M. Chenoweth // J. Am. Chem. Soc. 2016. 138 (31). P. 9751-9754.

8. Сметанина А.Б. Новые направления в производстве ветчинных консервов / А.Б. Сметанина, И.Г. Анисимова, О.В. Воробьева // Всё о мясе. - 2007. - № 5. - С. 28-31.

9. Lepetit J. Collagen contribution to meat toughness: Theoretical aspects // Meat Science. - 2008. - V. 80. - P. 960-967. 10. Жаринов А.И. Термическая обработка мясных изделий // Мясные технологии. - 2011. - № 1 (97). - С. 28-33.

11. Постников С.И. Современные белковые препараты животного происхождения Аля вареных колбасных изделий С.И. Постников, И.В. Рыжинкова // Мясная индустрия. 2009. - № 11. - С. 43-45.

12. Михайлов А.Н. Химия и физика комагена кожного покрова. М. -1980 . С. 166-183.

13. Wallace D.G. Multiple denaturational transitions in fibrillar collagen / D.G. Wallace, R.A. Condell, J.W. Donovan, A. Paivinen, W. M. Rhee, S. B. Wade // Biopolymers. - 1986. - №25 (10). P. 1875-1893.

14. Latorrea M.E. New recommendations for measuring collagen solubility / M.E. Latorrea, A.L. Lifschitzb, P.P. Purslowc // Meat Science. - 2016. V. 118. P. 78-81.

15. Семенова А.А. Функциональные свойства животного белка с низким рН и перспективы его использования в технологии сырокопченых колбас / А.А. Семенова, Е.К. Туниева, А.И. Рогатин // Все о мясе. - 2011. - №5. - C.40-41.

16. Игнатьева Н.Ю. Комаген - основной белок соединительной ткани (обзор). // Эстетическая медицина. - 2005. T. VI. - № 3. - C. 247-256.

17. Зайдес A.^. Структура комагена и её изменения при обработках. М. - 1960. - C.170-194.

18. Баблоян 0.0. Производство клея и желатина на кожевенных заводах / 0.0. Баблоян, А. П. Радкевич, Н.А. Тимохин // M.: 1972.174 c.

19. Sarbon N. M. Effects of different types and concentration of salt on the rheological and thermal properties of sin croaker and shortfin scad skin gelatin / Sarbon N. M., Cheow C. S., Kyaw Z. W., Howell N. K. // International Food Research Journal. - 2014. V.21 (1). P. 317-324.

20. Choi S. S. Physicochemical and sensory characteristics of fish gelatin / Choi S. S., Regenstein J. M. // Journal of Food Science. - 2000. - V. 65 (2). P. 194-199.

21. Changdao Mu. Collagen Cryogel Cross-Linked by Dialdehyde Starch / Changdao Mu, Fang Liu, Qingsu Cheng, Hongli Li, Bo Wu, Guangzhao Zhang, Wei Lin // Macromolecular Materials and Engineering. -2010, V. 295 (2). P. 100-107.

22. Stephan Busche. Collagen based functional proteins. // Fleisch wirtschaft international. - 2011. - №3. P. 48.

23. Семенова А.А. Влияние пищевых животных ингредиентов на гелеобразующую способность каппа-каррагинана / А.A. Семенова, М.В. Трифонов // Все о мясе. -2006. - №4. - С. 13-14. 24. Ladwig K. M. Effects of Collagen and Alkaline Phosphate on Time of Chopping, Emulsion Stability and Protein Solubility of FineCut Meat Systems / Ladwig K. M., Knipe C. L., Sebranek J. G. // Journal of Food Science. - 1989. V. 54 (3). P. 541-544.

25. Du C. Formation of calcium phosphate/collagen composites through mineralization of collagen matrix / Du C, Cui F. Z., Zhang W., Feng Q. L., Zhu X. D., de Groot K. // Journal of Biomedical Materials Research. - 2000. V. 50 (4). P. 518-527.

\section{REFERENCES}

1. Glotova I.A. Rheological characteristics of polyfunctional disperse systems on the basis of collagen animal proteins/ I.A. Glotova, Yu.V. Boltykhov// Uspekhi sovrmennogo estestvoznaniya. 2008. - No. 2. - pp. 43-44.

2. Omarov R.S. Proteins of animal origin in meat product manufacture . R.S. Omarov, O.V. Sycheva, S.N. Shlykov// Meat Industry. -2011 . - No. 3. - pp. 36-38.

3. Nekludov A.D., Ivankin A.N. Collagen: production, properties and use. - M.: GOU VPO MGUL. - 2007. pp. 12.

4. Gomez-Guillen M.C. Functional and bioactive properties of collagen and gelatin from alternative sources / M.C. GomezGuillen, B. Gimenez, M.E. Lopez-Caballero, M.P. Montero // Food Hydrocolloids. - 2011. - №25. - P. 1813-1827.

5. Rizk M. A, Mostafa N. Y. Extraction and Characterization of Collagen from Buffalo Skin for Biomedical Applications. Orient J Chem 2016;32(3).

6. Hashim et al. Collagen in food and beverage industries / P. Hashim, M. S. Mohd Ridzwan, J. Bakar, D. Mat Hashim // International Food Research Journal. - 2015. - V. 22(1). P. 1-8

7. Zhang Y. General Solution for Stabilizing Triple Helical Collagen. / Y. Zhang, M. Herling, D.M. Chenoweth // J. Am. Chem. Soc. 2016. 138 (31). P. 9751-9754.

8. Smetanina L.B. New directions in canned ham manufacture / L.B. Smetanina, I.G. Anisimova, O.V. Vorobieva // All about meat. - 2007. - No. 5. - pp. 28-31.

9. Lepetit J. Collagen contribution to meat toughness: Theoretical aspects // Meat Science. - 2008. - V. 80. - P. 960-967.

10. Zharinov A.I. Thermal treatment of meat products // Meat technologies. - 2011. - No. 1(97). - pp. 28-33.

11. Postnikov S.I. Modern protein preparations of animal origin for cooked sausage products / S.I. Postnikov, I.V. Ryzhinkova // Meat Industry. - 2009. - No. 11. - pp. 43-45.

12. Mikhailov A.N. Chemistry and physics of skin collagen. M. 1980. pp. 166-183.

13. Wallace D.G. Multiple denaturational transitions in fibrillar collagen / D.G. Wallace, R.A. Condell, J.W. Donovan, A. Paivinen, W. M. Rhee, S. B. Wade // Biopolymers. - 1986. — № 25 (10). P. 1875-1893.

14. Latorrea M.E. New recommendations for measuring collagen solubility / M.E. Latorrea, A.L. Lifschitzb, P.P. Purslowc // Meat Science. - 2016. V. 118. P. 78-81.

15. Semenova A.A. Functional properties of animal protein with low $\mathrm{pH}$ and prospects for its use in the technology of uncooked smoked sausages / A.A. Semenova, E.K. Tunieva, A.I. Rogatin // All about meat. - 2011. - No.5. - pp. 40-41.

16. Ignatieva N.Yu. Collagen - the main protein of the connective tissue (a review). // Esteticheskaya medicina. - 2005. Vol. VI. - No. 3. - pp. 247-256.

17. Zaides A.L. Structure of collagen and its changes upon treatments. M. - 1960. - pp. 170-194.

18. Babloyan 0.0. Production of glue and gelatin in tanneries / 0.0. Babloyan, D. P. Radkevich, N.A. Timokhin // M.: 1972 174 pages.

19. Sarbon N. M. Effects of different types and concentration of salt on the rheological and thermal properties of sin croaker and shortfin scad skin gelatin / Sarbon N. M., Cheow C. S., Kyaw Z. W. Howell N. K. // International Food Research Journal. - 2014. V. 21 (1). P. 317-324

20. Choi S. S. Physicochemical and sensory characteristics of fish gelatin / Choi S. S., Regenstein J. M. // Journal of Food Science. - 2000. - V. 65 (2). P. 194-199.

21. Changdao Mu. Collagen Cryogel Cross-Linked by Dialdehyde Starch / Changdao Mu, Fang Liu, Qingsu Cheng, Hongli Li, Bo Wu, Guangzhao Zhang, Wei Lin // Macromolecular Materials and Engineering. - 2010, V. 295 (2). P. 100-107.

22. Stephan Busche. Collagen based functional proteins. // Fleisch wirtschaft international. - 2011. - №3. P. 48.

23. Semenova A.A. Effect of food animal ingredients on gel forming capacity of kappa-carrageenan / A.A. Semenova, M.V. Trifonov // All about meat. - 2006. - No.4. - pp. 13-14.

24. Ladwig K. M. Effects of Collagen and Alkaline Phosphate on Time of Chopping, Emulsion Stability and Protein Solubility of FineCut Meat Systems / Ladwig K. M., Knipe C. L., Sebranek J. G. // Journal of Food Science. - 1989. V. 54 (3). P. 541-544.

25. Du C. Formation of calcium phosphate/collagen composites through mineralization of collagen matrix / Du C, Cui F. Z. Zhang W., Feng Q. L., Zhu X. D., de Groot K. // Journal of Biomedical Materials Research. - 2000. V. 50 (4). P. 518-527. 


\section{СВЕДЕНИЯ ОБ АВТОРАХ}

Принадлежность к организации

Дроздова Надежда Александровна - кандидат технических наук, научный сотрудник направления «Технология колбас, полуфабрикатов и упаковки» отдела «Научно-прикладных и технологических разработок», Всероссийский научно-исследовательский институт мясной промышленности имени В.М. Горбатова

109316, г. Москва, ул. Талалихина, 26

Тел.: 8-495-676-61-11

E-mail: drozdova@vniimp.ru

Насонова Виктория Викторовна - кандидат технических наук, руководитель направления «Технология колбас, полуфабрикатов и упаковки» отдела «Научно-прикладных и технологических разработок», ФГБНУ «Всероссийский научно-исследовательский институт мясной промышленности имени В.М. Горбатова»

109316, г. Москва, ул. Талалихина, 26

Тел.: 8-495-676-65-51

E-mail: nasonova@vniimp.ru

\section{Критерии авторства}

Авторы в равных долях имеют отношение к написанию рукописи и одинаково несут ответственность за плагиат.

Конфликт интересов

Авторы заявляют об отсутствии конфликта интересов.

Поступила 09.08.2016

\section{AUTOR INFORMATION}

Affiliation

Drozdova Nadezhda Alexandrovna - candidate of technical sciences, research scientist of the Direction of Technology of Sausage Products, Semi-Finished Products and Packaging of the Department of Scientific Applied and Techno-logical Developments, The V.M. Gorbatov All-Russian Meat Research Institute

109316, Moscow, Talalikhina str. , 26

Tel.: 8-495-676-61-11

E-mail: drozdova@vniimp.ru

Nasonova Viktoria Viktorovna - candidate of technical sciences, leading research scientist, the Head of the Direction of Technology of Sausage Products, Semi-Finished Products and Packaging of the Department of Scientific Applied and Technological Developments, The V.M. Gorbatov All-Russian Meat Research Institute

109316, Moscow, Talalikhina str. , 26

Tel.: 8-495-676-65-51

E-mail: nasonova@vniimp.ru

\section{Contribution}

Authors in equal shares are related to writing of the manuscript and equally bear responsibility for plagiarism.

Conflict of interest

The authors declares no conflict of interest.

Received 09.08.2016 